\title{
The hydrological networks of the Balkh Oasis after the arrival of Islam: a landscape archaeological perspective $^{1}$
}

\section{Abstract}

This article seeks to evaluate the development of the Balkh Oasis in Northern Afghanistan, from the perspective of hydrological management. The concept of 'oasis cities' has been applied to several lowland settlement systems in Central Asia, characterised as fertile river deltas surrounded by deserts. Of these, the oasis surrounding the city of Balkh remains the least well archaeologically explored, in spite of the fact that it represents possibly the best preserved of similar hydrological systems. As new archaeological ground survey in the Balkh region remains challenging, the discussion here compares existing archaeological records and historical accounts of water management throughout the medieval and early modern period, combining them with evidence traced from high-resolution satellite imagery. The picture that emerges is a complex constellation of substantial settlements among agricultural lands beyond the core city, watered by tiers of divergent channels. Several key changes in the physical and political landscape necessitated the reorganisation of this hydrological network, and over time these shifts can be traced by contrasting the abandonment of some regions with the notable expansion of others.

\section{Keywords}

Balkh, Hydrology, Archaeological Survey, Islamic Archaeology

\section{Introduction}

The geography of Central Asia is highly varied, encompassing vast steppe grasslands, arid deserts and high mountain ranges, from the expanses of the Kazakh marches to the ragged peaks of the Pamirs and the Hindu Kush. The core political heartlands of the early Islamic 
empires in the region, however, were generally confined to lowlands in the range of an arid to semi-arid climate, where key nodal settlements were located in fertile endorheic river deltas, ${ }^{2}$ surrounded by uncultivable land. While similar hydrological systems exist elsewhere in the world, the particular conditions of the Central Asian rivers and historical local land management practices formed a particular regional urban-rural model. The resulting oasis cities are seemingly arranged in a comparable pattern: a central hub, surrounded by an array of smaller towns and forts, connected by a complex lattice of canals distributing water resources within a clearly defined fertile zone.

Several of these oasis systems were investigated from archaeological and historical perspectives over the $20^{\text {th }}$ century, most notably by Soviet teams across the former territories of the USSR, ${ }^{3}$ and have increasingly attracted the attention of foreign scholars since independence. ${ }^{4}$ Somewhat less well-known, owing to political-geographic constraints, are the similar systems in Northern Afghanistan, among which the delta of the Balkh river has been the largest and most populous since the arrival of Islam. The central point of this system, the city of Balkh itself, has been the subject of considerable archaeological research, but these studies have mainly targeted the remains of the pre-Islamic period. ${ }^{5}$ While the medieval florescence of the city is well supported by detailed historical studies of the urban topography, ${ }^{6}$ very little archaeological evidence has been recovered to elucidate the material culture of the urban milieu during this time. Meanwhile, the role of the city as part of the broader oasis system has until recently remained largely elusive. Two critical studies began the process of framing Balkh in the context of its hinterland. McChesney’s analysis of waqf documents relating to the shrine of Ali in modern Mazar-e Sharif deconstructed the politics of land management in the oasis and the distribution of water from the Balkh-ab. ${ }^{7} \mathrm{~A}$ contrasting approach to the hydrological landscape was adopted by Fouache and colleagues 
who interpreted data from environmental cores to investigate early canal formation in the region. $^{8}$

This article builds on these two studies by analysing in detail the available evidence for the oasis of Balkh as a 'system' in the early Islamic period.

In order to reconstruct the geography of the canal system, it is necessary to consider the layout of the delta over a long time period, the longue durée if you will, as historical and archaeological data from the first centuries after the Arab conquests is currently insufficiently detailed to chart the evolution of the network. Luckily, it is possible to trace glimpses of the early hydrology of Balkh and its hinterland, by combining the available data providing an insight into the organisation of this system. In particular the ever-increasing accessibility of satellite imagery in has permitted the reassessment of existing fragmentary archaeological data in an area where large-scale ground survey remains challenging.

This brief investigation examines firstly the environmental setting of the Balkh River, before exploring the historical evidence for the systematic exploitation of its various channels, considering sources from the tenth to the seventeenth centuries. Although several scholars have assessed some of this data, the focus of this study is to place the Balkh canals and the villages that they water in a spatial context, made possible through a comparison with modern topographical gazetteers. The aim of collating the information in this way is to compare it with settlements attested archaeologically - from regional survey work and by remote detection using high-resolution satellite imagery. The resulting picture that emerges highlights the connectedness of the city of Balkh as part of a network of medium-sized towns, and the relationship between changing settlement patterns in the delta and water distribution. 
The Balkh-ab and the development of Balkh

The northern plains of Afghanistan, shrouded by the Hindu Kush, are generally categorised as a cold-arid steppe climate. Almost all of the zone from the piedmont to the Oxus receives on average fewer than 200mm precipitation per annum, restricting rain-fed agriculture to small-scale cultivation in wet seasons, and necessitating large-scale irrigation in order to sustain intensive farming. ${ }^{9}$ Although palaeoclimatic data is patchy for this region, core samples from the Aral Sea suggest that notwithstanding major fluctuations in the late medieval/early modern period this area would have experienced similar conditions to the present day throughout the second half of the first millennium CE. ${ }^{10}$

By the time of the Arab conquests, the delta around Balkh was already a densely populated agricultural landscape, with numerous small cities or towns, fields and irrigation. As the extant capital of the region, one of the key objectives of the early caliphal expansions (under al-Aqra $^{~}$ b. Habis, Qays b. al-Haytham, and later Qutayba) ${ }^{11}$ was to capture and maintain a foothold in the city of Balkh. However, the resultant inheritance was not simply an isolated urban centre, but an intricate system of settlements relying on the regional management of water resources from a single river. Owing to the fact that the hinterland of Balkh was entirely dependent upon perennial irrigation, the city was part of a much larger system engineered to maximise the use of the Balkh River or Balkh-ab (Figure 1).

\section{[insert Figure 1 here]}

Rising in the central Hindu Kush, the Balkh-ab reaches its eponymous plain through a narrow gorge at Cheshmeh-ye Shafa, literally the 'spring of healing', whereupon it divides to irrigate an area of over 400,000 hectares in the present day. ${ }^{12}$ The dendritic alluvial network, which is the product of both natural and human rerouting of river channels, has been the subject of investigation from the perspective of modern hydrological management, but has also been analysed in order to reconstruct the sequence of its formation. The study undertaken by 
Fouache and colleagues incorporated archaeological data as well as absolute Optically Stimulated Luminescence (OSL) dates taken from wells bored into the sediments of different zones of the delta and concluded that the four main branches of the river represented major (natural) shifts in its course, which correspond to shifting historical settlement patterns. ${ }^{13}$ According to their palaeoenvironmental study, the latest major natural redirection of the river can hypothetically be linked to a sizeable earthquake recorded by Ibn al-Athir in 819 CE, ${ }^{14}$ which precipitated a westward shift of the river course and created a new sub-delta where the city of Aqcha was subsequently founded. ${ }^{15}$ That water was suddenly brought to a previously barren region following an earthquake is supported by a note in Qudama b. Ja far's itinerary of the route from Marv al-Rud to Balkh. According to his account, the earthquake caused a spring to open up at al-Sidra, from whence water poured into the desert. ${ }^{16}$ The date that he gives for this event, $203 \mathrm{AH}$ (818-819 CE), broadly fits with the OSL dates assigned to this branch of the river system by Fouache and colleagues. ${ }^{17}$ Given the distances specified in the geographical itineraries of the tenth century, the site of al-Sidra is thought to be synonymous with the modern city of Aqcha, being the largest centre in this part of the oasis. ${ }^{18}$ Our current knowledge of historic settlement patterns for the Aqcha section of delta remains poor, but according to Fouache and colleagues, this area was not occupied in the pre-Islamic period, as there were no active channels flowing in this direction prior to the aforementioned seismic event. Archaeological surface surveys have, however, identified ceramics from as early as the third century BC at the archaeological sites of Parishan Tepe, Khalabad Tepe, and Tepe Qabr-i Turkman, ${ }^{19}$ suggesting that there was water flowing to this region well before the arrival of Islam. The largest of these, Parishan Tepe, was recorded by Barger and Wright with 'an extensive system of ancient irrigation channels now dried up,' ${ }^{20}$ visible alongside extensive field systems and rural settlement in modern satellite imagery. In fact, during a brief exploration of the latter, Shakur also noticed that unlike the other tell sites in 
the region, there was apparently no evidence at Parishan Tepe of Islamic occupation. ${ }^{21}$ Many further sites have been located southeast of Aqcha, but some remain as yet undated, like the citadel of Aqcha itself, and there is clearly a great deal more work to be done to clarify the settlement in this zone. A brief re-examination of the finds gathered by Barger and Wright in the area, however, confirmed that all of the sites they collected material from included glazed ceramics dating from between the tenth-fifteenth centuries CE. ${ }^{22}$ Just east of Parishan Tepe, a series of sondages at Nimlik (Minglik) represents the most intensive study of any settlement in this area, and these small stratigraphic 'windows' also identified continuous occupation from the Achaemenid period until the early modern period. ${ }^{23}$

A noticeably absent piece of this puzzle is the occupation history of the city of Aqcha/alSidra itself, represented by the large fortified tell site just north of the modern town.

Unfortunately no research has attempted to elucidate a foundation date for the central citadel, but on the basis of its height and comparing the form to similar monuments of the Balkh oasis, it is highly likely that in fact there was pre-Islamic occupation at this site. The name 'Aqcha' only appears in later references, with possibly the first mention in the early seventeenth century account of Mahmud b. Amir Wali. ${ }^{24}$ Presumably before this date the settlement is known by its alternative name, al-Sidra, although this is by no means clear. I cannot find any mention of either al-Sidra, or Aqcha between the twelfth-seventeenth centuries. $^{25}$

In spite of the evidence for existing settlement in the Aqcha region, the fundamental impact of a general westwards shift of the main river course system should not be understated. To the single 'core' delta that had been centred on Balkh ${ }^{26}$ was appended a somewhat distinct sub-delta around Aqcha, although in the southernmost part, along the river channel of the Balk-ab, the presence of settlements continues seamlessly between the two. Such a dramatic alteration in regional hydrology must also have had a significant effect on the irrigation and 
water-provision strategies for the city of Balkh. The redirection of the major flow of water would have necessitated a complete reorganisation of the Balkh-ab system, at a time when the region had also recently been plagued by widespread famine in 916-917. ${ }^{27}$ Although there is clearly significant evidence of complex irrigation prior to the ninth century, the inundation of the western region can thus be seen as a starting point for the new hydrological networks of the Balkh plain throughout the middle Islamic period.

The canal network in the Balkh oasis - historical data Most of the medieval authors writing about the city of Balkh mention its water provision at least to some degree. Some, like al-Moqaddasi, merely mention that in the tenth century the city and its hinterland are well watered, without enumerating the individual streams and canals that flow through it, or giving their names. ${ }^{28}$ Meanwhile any of the early maps that accompany the geographic texts, give no indication whatsoever of the river, ${ }^{29}$ and others give simplified view, connecting it to the Amu Darya. ${ }^{30}$ The anonymous tenth century Hodud al'Alam describes the first real details of the irrigation system, apparently comprising twelve channels that irrigate the agricultural lands around the city. ${ }^{31}$ Interestingly, the unknown author also mentions that there are many marshes in the region around Balkh, suggesting that there was significant surplus in the hydrological system at this time, possibly relating to higher flow than existed at the initial planning of the canals.

For a much more detailed account of the water system in the oasis it is necessary to consult texts from the early modern period, most notably the partially surviving account of Hafez-e Abru, ${ }^{32}$ from the first half of the fifteenth century, and the comprehensive accounts of the seventeenth-eighteenth century, such as the Jarida of Mohammad Mo'min ${ }^{33}$ and the anonymous Tarikh-e Raqimi. ${ }^{34}$ As both the latter accounts are strikingly similar we can assume that they originate from the same source, but it is not certain when this description 
was first laid down. From the early modern period onwards, the canal system is known as the 'Hazhda Nahr', ${ }^{35}$ or 'Eighteen Canals', a name which still persists. Further details of canals as they continued to function in the nineteenth century are described by Russian and British travellers, but by the time of imperial travellers there are clearly sections which have long since dried up or been diverted. All authors, from the medieval period to the modern, appear to agree that origin of the system was a combination of existing natural stream courses and purpose-made canals, which were regularly re-dug.

Hafez-e Abru mentions a total of twenty-one canals, with one further river included as part of the same system. What survives of his account is somewhat fragmentary, for example for several of the named canals we have no information about the villages watered by them and there are discrepancies in the detail between the surviving manuscripts. Nevertheless, fifteen of the villages can be matched with the later sources (see below), and thus pinpointed in the landscape, while eight of the canal names continue in use according to early modern texts. Unlike later accounts, the description of Hafez-e Abru does not present the canals following a logical geographical sequence, and the list must have been structured according to some other principle. Unfortunately this precludes the possibility of even roughly interpolating the locations of the missing canals based on their sequence. His text is also the first indication that some of the key settlements outside of the city of Balkh, lend their names to the canals (Adina Masjid, 'Ali Abad, and Dastjerd, for example). There are, however, too few securely recognisable toponyms to reconstruct the vast majority of the system, owing to considerable name changes or inconsistencies between sources.

Subtelny notes that periods of renovation and re-excavation coincided with the reorganisation of the system, and she extrapolates this process to account for the differences between the account described in Hafez-e Abru and that of the later authors. ${ }^{36}$ This may explain to some degree the changing names of the canals between the fifteenth and seventeenth centuries 
although the origins of Hafez-e Abru’s information may also be from different or even much earlier sources. By the next major description of the system that survives, the Jarida, there is sufficient further data (in the form of administrative documents and waqf deeds ${ }^{37}$ ), to crossreference some of the names mentioned, but even this account itself is sufficient to document where these canals are located. Mo'min divides the canals of the Balkh delta into four groups, based on the locations at which they branch from the Balkh-ab. ${ }^{38}$ An important locus for the determination of these branching points is the Pol-e Imam Bokri (Figure 1), one of the only bridges mentioned on the main branch of the river, connecting to the road leading southwards towards the mountain pass of Cheshma-ye Shafa and on to Bamiyan. Only one dam is named, further down the river at Band-e Sukhta, and all of the other channels seemingly derive directly from the river channel itself. ${ }^{39}$ It has been suggested that the terminal point of the main branch of the Balkh-ab was already at this time the eastern side of the Aqcha delta. ${ }^{40}$ In spite of Mukhtarov's assessment that the majority of names have changed between the seventeenth century and the present, a reappraisal of modern cartographic and toponymic material reveals that it is in fact possible to reconstruct a large proportion of the irrigation system.

In the reconstruction diagrams presented here (Figures 2 and 3), historical settlements were mapped onto modern toponyms in a GIS platform, using the USAID’s MISTI (Measuring Impact of Stabilization Initiatives Survey Dataset) database. ${ }^{41}$ These were compared with the toponyms that appear on Soviet 1:50,000 maps ${ }^{42}$ and the data collated in the Historical and Political Gazetteer of Afghanistan. ${ }^{43}$ Combining these sources with modern satellite imagery, it was possible to plot the location of 80 of the 271 qishlaqs (villages) mentioned in the account of Mo'min. While in a handful of instances the cross-identification of the village names was tentative, for most, their relative position within the canal system and historical prominence enabled them to be pinpointed with reasonable certainty. Conversely, minor 
settlements and those whose names had changed radically were impossible to locate. By dividing the area of the Balkh delta between the mapped settlements algorithmically, it was possible to assign each of these villages a 'zone' in the GIS map and thus view the approximate areas irrigated by each canal, and their course through the system (Figure 2). ${ }^{44}$

\section{[insert Figure 2 here]}

As a primary observation, it is evident that it is necessary to look critically at the ordering of Mo'min’s toponyms. Although the canals appear to be listed in an anti-clockwise fan from the easternmost branch towards the west, the western branches are not so clear. Similarly, while it is tempting to assume that the listed villages are a linear description of the course of the canals, in several instances subsidiary canals, branches or juys (ditches) are included without specific designation as such. That some of these smaller branches are labelled as anhar in their own right, explains in part the variant number of canals in different sources, and the odd fit of the eighteen-canal name. It should be mentioned, however, that for some of the canals, the names of the villages are clearly not in any assigned order, whereas for others, they appear to be in a logical progression from the south to the limits of the canal in the north.

The lack of identifiable villages for four of the canals, disallows their reconstruction in the diagram mentioned above, although it is possible to hypothesise about their placement. Most notable among these is the Nahr-e Shahi, the first of Mo'min's list, which features also in later descriptions, albeit with very different toponyms for the villages it waters. The Nahr-e Shahi is particularly important because, as McChesney and Subtleny have demonstrated, the renovation and expansion of this canal (and indeed its probably renaming) was tied to the expansion of the cult site of the shrine of 'Ali, in what is now known as Mazar-e Sharif. ${ }^{45}$ This eastern expansion of the delta is discussed in greater detail below, but for the purposes of Figure 2, we can assume that the course of the Shahi followed an almost due eastwards 
course from the Pol-e Imam Bokhri, more or less identical to canal feeding Mazar-e Sharif today. The reason for the complete shift in the toponyms of the villages in this area is likely also linked to the rapid development in this zone, again connected with the growth of the shrine and the endowment of lands surrounding it. The second important canal which cannot be placed owing to the lack of recognisable toponyms is the Nahr-e Dastjerd, which is also mentioned in Hafez-e Abru's text. ${ }^{46}$ The town of Dastjerd or Dastajerda, after which the canal was named, appears to have dwindled in importance from its prominent place on the high road west from Balkh in the tenth century, ${ }^{47}$ to disappear completely in modern accounts, and unfortunately appears to be undiscoverable.

In order to draw a comparison with this data, and to expand the details of how the system changed over time, it is necessary to look even further forward in time, to the era of Imperial interests in Central Asia. The nineteenth century saw a proliferation of western European exploration and documentation of this border region, and additional details of the hydrological system were collected by the Afghan Boundary Commission, presented concisely in the later Gazetteer of these works by Adamec. ${ }^{48}$ Of the eighteen canals mentioned by Major Maitland (in Adamec), ten names are identical to those outlined by Mo'min, and a significant number (75, or $48 \%$ of all villages located through the cartographic/toponymic reference listed above data) of the village names can be matched between the two (Figure 3).

\section{[insert Figure 3 here]}

While a general comparison between the two texts gives the impression that in several instances the villages came to be watered by different canals in later periods, the extra level of detail presented in the Adamec synthesis, combined with the geographical data allows the reconstruction of more complex relationships between the 'eighteen' canals listed. The Nahre Quddar mentioned by Mo'min is described by Maitland as originating from the same point 
as the Nahr-e Shahi, ${ }^{49}$ while the Nahr-e 'Abd Allah and the Bakhshawar canal are branches of the Nahr-e Isfahan and the Nahr-e Dawlatabad respectively. ${ }^{50}$ Comparing the later model with the Mo'min village names, it is evident that in fact the system may not have changed so dramatically. Indeed, where almost all of the canals in the Jarida are assumed to stem from the main channel of the river, this was seemingly never the case.

The canal network in the Balkh oasis - archaeological data

How, then, do these models compare to the archaeological and palaeoenvironmental data for the delta? As with the westward shift towards Aqcha, the archaeological site data collated by Ball indicates an overall pattern for settlement around Balkh itself (Figure 1). Many of the dramatic changes in the pre-Sasanian period are documented by Fouache and colleagues, ${ }^{51}$ but it serves the purposes of this article to highlight specifically the changes that appear to have occurred following the spread of Islam. Overall, the sites with documented material from the eighth century onwards occupy a much more condensed area than those with solely pre-Islamic finds, and are clustered towards the south of the alluvial zone. The archaeological material is not systematically recorded, however, as it is aggregated from a series of very diverse field reports. With the increase in available high-resolution satellite imagery, it is possible to compare the observed sites with the overall distribution of sites. In an arbitrary sample area $(25 \mathrm{~km} \times 15 \mathrm{~km})$ to the north of Balkh where there are almost no sites recorded in Ball's Gazetteer, 38 tell sites were recorded, excluding those under 1ha (Figure 4). ${ }^{52}$

\section{[insert Figure 4 here]}

While only covering a limited area, this type of mapping highlights the general density of abandoned settlements in the delta area, many of which undoubtedly have both Islamic and pre-Islamic occupation. Unfortunately current security issues prevent large-scale groundtruthing, although a large amount of data collected through many years of working in the region is currently being analysed by the Délegation Archéologique Française en Afghanistan 
(DAFA). ${ }^{53}$ Only through the accurate dating of these sites will it eventually be possible to reconstruct detailed shifts in settlement patterns. The existence of clusters of tell sites in zones with no modern occupation (including much of the area mapped in Figure 4), supports the idea that the disuse of several sub-channels of the original hydrological system led to complete abandonment of some regions.

Satellite imagery also gives an impression of the characteristics of some of the sites mentioned in the account of Mo'min and earlier historical texts. Siahgird for example, is a substantial complex settlement (the core of which measures approximately 3km x 3km), clearly with many different phases in the northernmost part of the delta, on the route to Termez (Figure 5). From an assessment of the remains from aerial imagery (Figure 5), it is possible to identify both an extensive settlement, and a much larger irrigated area (over 300 ha), suggesting that this locale was more than simply a fortified outpost protecting the edge of the cultivated zone.

\section{[insert Figure 5 here]}

The limited archaeological work at Siahgird has focused on one part of the site, namely Yarti-Gombaz to the north of the built up area, which identified what appears to be a Buddhist stupa dating from the sixth-seventh century CE. ${ }^{54}$ No other dating evidence has firmly determined the origins of this site but it is included in ninth-tenth century geographical itineraries ${ }^{55}$ and in contemporary texts relaying the earliest details of the function of the canal system. ${ }^{56}$ Into the eleventh century, Siahgird clearly continues to play an important role as the main waypoint between Balkh and the Amu Darya, appearing twice in Beyhaqi's account of the peregrinations of the Ghaznavid court. ${ }^{57}$ Unfortunately none of the geographical accounts provides an estimate of the size of the settlement in the early Islamic period and it is only possible to tentatively assume the maximum extent of the remains visible on the surface broadly relate to the pre-Mongol period. 
Neither do we gain any impression of the size of the settlement in later periods. Mo'min mentions Siahgird in connection with its position on the eponymous canal, suggesting it was still a key irrigated node in the seventeenth century. According to Peacocke’s assessment, however, by 1886 the site was long-abandoned and in ruins, much as it is today, although consulting the local inhabitants of the nearby village, he could not establish exactly when this came about. ${ }^{58}$ In a trend that mirrors similar settlements across the delta, the modern village of Siahgird is a much smaller settlement, situated further upstream, closer to the core of the delta (albeit still demarcating the northeastern limit of the canal).

A similar situation can be observed at Zadiyan, with a central citadel surrounded by field systems all enclosed within an extensive walled rectangular area $\left(4 \mathrm{~km}^{2}\right.$, Figure 6$) .{ }^{59}$ The form of this settlement is strikingly different from Siahgird, being more formally laid out, with a monumental citadel and square outer area, apparently occupied by a very regular network of fields (although these are not demonstrably contemporary with the settlement). Outside the regular walled enclosure a minaret dating to $1108 \mathrm{CE}^{60}$ attests occupation at the site at least as early as the Seljuq period, ${ }^{61}$ while Le Berre's summary suggests that the area could have been laid out from the first centuries CE. ${ }^{62}$ In contrast to Siahgird, however, Zadiyan is not mentioned on route itineraries, and although at the fringe of the cultivable delta its location cannot be explained simply as an isolated finger of agricultural expansion stretching out towards the banks of the Amu Darya. Instead it is clear that Zadiyan represents one of several large settlements that flourished at the fringes of the river system accompanied by substantial agricultural hinterlands, in spite of being entirely dependent on the same network of hydrological distribution as the myriad smaller villages to the south.

\section{[insert Figure 6 here]}

These two brief examples are not exceptional; they in fact represent a broader trend. The site known as Khanabad at the present day, on the outer reaches of the Nahr-e Shaykh Shurak is 
similar in layout to Zadiyan, ${ }^{63}$ and a similar size. The large settlement of Adina Masjed is again at the end of the eponymous canal, although geographically slightly closer to the core of the Balkh oasis, which perhaps explains why unusually a large village still persists there to the present day. To a certain extent the presence of these towns at the edge of the oasis can be attributed to the importance of trade between Balkh and the Amu Darya, as these last two examples are known to be situated along other northbound routes. ${ }^{64}$ Their size and spread, however, along with the extensive field systems around them, highlights that these towns are not merely caravanserais and the system of canals as (re-) conceived in the early Islamic period at is designed to provide them with sufficient water to flourish.

Combining all of the data above we can draw several important conclusions. The early Islamic period saw a shrinking of the total extent of irrigated zone of the core Balkh delta, with two hypotheses standing out for the causes of this phenomenon. The first is the diversion of some of the water towards the Aqcha delta, which appears to be expanding at this time, in part owing to tectonic activity. The second is the densification of settlement in the lower part of the delta around Balkh itself, which is supported by the formalisation of the canal system described in the Arabic and Persian sources. Finally, in perhaps the contrary of what might be expected for this geographical formation, larger settlements exist at the fringes of the delta, while the core of the delta comprises smaller settlements and agricultural lands. As well as these cities being clearly visible on the satellite imagery, the popular names for several of the canals (for example the Nahr-e Siahgird, Nahr-e Adina Masjed) highlight the prominence of these seemingly marginal settlements and perhaps suggest the chief structuring principle of the system. The canals were designed to bring sufficient water to these principal settlements at the edge of the oasis, whereupon smaller development was promoted along the lower reaches of each branch (and is thus less visible archaeologically), but carefully controlled in order to maintain a balanced network. 


\section{Hydrology as a network}

As illustrated above, the system of water supply in Balkh was not simply a series of directed conduits; it functioned through several tiers that enabled the control of the flow at key junctions, and thus the apportionment to different branches. As each settlement or qishlaq depended on a specific channel (or in some cases two), so these channels were dammed at sequential points, allowing centralised control of the water resources. While the impression given by Mukhtarov is clearly that the dams were all situated at the junctions of off-takes from the main channel of the Balkh-ab, in some instances several sub-channels were reliant on a single dam.

Although we have very few details as to the maintenance of the hydrological system at Balkh in the early Islamic period, some light can be shed on the practice of water administration from the nearby oasis city of Marv. Al-Estakhri mentions that water for the city was collected in a hauz (reservoir) before the city and then divided between the channels that fed the urban area by a system of wooden boards with holes in of a specified size, which controlled the flow. ${ }^{65}$ At the head of the administration of this system overall was an amir wielding considerable civic power. According to the detailed account of al-Khwarazmi, however, the water system in the Murghab delta was overseen (and taxed) by the Diwan al-Kastabzud (seemingly from kast wa afzud - rising and falling), who kept accounts of those with water rights, and the transactions of these rights. ${ }^{66} \mathrm{Al}-$ Moqaddasi likewise mentions the Diwan al$N a h r$ and its role in monitoring both the water level and the dam, in terms of maintenance. ${ }^{67}$ The resulting depiction of the water systems in Marv is therefore not only one of centralised organisation, but hierarchical structure in terms of distribution. Considering the position of the district capitals within the systems of Marv and Balkh respectively, it would be logical that they are placed at or near the major branching point. Nevertheless, neither of these cities is placed to control the damming of the rivers, nor are they on isolated streams where the 
majority of the flow would be reserved for the urban populace. Viewed in this context, both Merv and Balkh are inseparable from the smaller towns and villages surrounding them, which are ultimately part of the same system. This system was controlled in a centralised manned by the urban administration, who ensured an even and measured flow across the channels. Ultimately, however, this rendered the damming points vulnerable to attack, as in the case of Merv after Sanjar's death in 1167, with the immediate effect of flooding the cities but ultimately causing entire branches of the network to dry up, and become depopulated. A similar technique was employed by the Mongols to flood Samarkand with the waters of the Zarafshan, in retribution for its resilience. ${ }^{68}$ In Balkh, several early modern military campaigns utilised the control of canals either to besiege or destroy the city, ${ }^{69}$ and eventually the lack of maintenance appears to have led to the almost complete abandonment of the city in the nineteenth century. ${ }^{70}$

To gain a better idea of administration of water in the Balkh oasis, we must turn again to the early modern period, where better documentation survives in terms of the division of water. A survey of the water rights and allocations of agricultural land in the Balkh oasis has already been outlined in two studies: namely Robert McChesney’s comprehensive study of early modern waqf documents from the region and Maria Subtelney's analysis of the endowment of the shrine of 'Ali in what is now Mazar-e Sharif. According to their source materials, the growth of the shrine in the east of the delta was accompanied by a series of endowments, which included the apportionment of water rights of the Nahr-e Shahi as well as from other parts of the oasis. ${ }^{71}$ Subtelny gives the specific example of documents describing shares in the Palaspush canal, a branch of the Nahr-e Balkh, which were sold and repurchased, she argues, for the purpose of conveying them to waqf for the 'Alid shrine. ${ }^{72}$ This, however, is just one of many examples of water shares that were reallocated as part of this general reorganisation, or reorientation of the Balkh-ab system. It is difficult to demonstrate the 
direct physical impact of the conveyance of water rights, as there is no clear evidence whether or not it was just the revenues from the distribution of the water that contributed towards the endowment, or whether the water itself was reallocated. The growth of the area around the Nahr-e Shahi, however, would suggest the latter. In part owing to the position of this canal, at one of the highest points in the oasis system, an increased amount of water diverted to the eastern region would have had a dramatic impact on the irrigation of the plains. This process is supported by the impression of the progressive abandonment of the outer areas of the Balkh oasis and the thinning of settlements along specific juys in the Balkh region. That Palaspush is specifically mentioned in the sales deed quoted by Subtelny is telling, as there is a distinct change between Mo'min's description of the Nahr-e Isfahan, and that of Adamec (compare Figures 2 and 3). While the lower villages in the area immediately around Balkh, such as Chahar Gonbad, Chaharbagh-e Gulshan and Palaspush itself continue to be irrigated by this canal between the sixteenth and nineteenth century, the water does not appear to have reached the northernmost areas of the delta. A similar situation can be observed with the Nahr-e Arghandab, which, although it appears in Adamec's general catalogue, ${ }^{73}$ is not mentioned among Maitland's list of the Hazhda Nahr. While some of the corresponding villages are irrigated by the Shaykh Shurak canal in the later period, at least five settlements from Mo'min's description of this canal disappear completely from the historical record.

As a post-script on this process; the exponential growth of Mazar-e Sharif as an administrative regional centre in the twentieth century saw the redirection of even greater amounts of water away from the older Balkh-ab system. The number of derelict historical channels has increased dramatically over the last hundred years, creating a number of comparatively dry areas around Balkh, where the archaeological remains are exceptionally well preserved (as demonstrated above). It should be noted, however, that a substantial 
proportion of the Balkh-ab delta still remains actively irrigated via the canal system documented above, a testament to the processes of maintenance and periodic re-excavation of the channels which keeps the plain fertile.

\section{Watering the city}

Having examined the region surrounding Balkh, it is necessary to consider the position of the city itself in this network. The walled urban area is geographically at the centre point of the delta, and while seemingly positioned in part for this reason (well before the Islamic conquests), it by no means dominates the distribution grid. The absence of physical topographic evidence of canals directly watering parts of the walled city is notable, while providing flowing water for the continued occupation of the high citadel would have been problematic. ${ }^{74}$ In spite of the description in both the Hudud al- 'Alam and Hafez-e Abru's geography that the river runs through the middle of the city (be mian-e shahr migozard), ${ }^{75}$ there is almost no trace of historic canals within walls, unlike at Marv, where the traces of the Majan canal clearly define the central axis of the ninth-thirteenth century city. ${ }^{76}$ Nevertheless, it is certain that the canals watered the walled suburban areas at the very least. Ibn Hawqal details that in Balkh, the city canal, a branch of the Balkh-ab, went through the Nawbahar gate, thus irrigating the suburb. ${ }^{77}$ The majority of modern authors have located the Nawbahar gate through the southern wall of the city, closest to the ruins labelled Top-e Rostam, which is thought to be the Naw Bahar itself. Assuming this designation is correct, there is no longer any evidence on the ground of the existence of a canal here, and a photograph showing the extant gate in 1924 shows no sign of a substantial channel, although this could be from a later renovation. ${ }^{78}$ Excavations through the southern wall revealed a structure which seemed to be an early water gate and channel, but the ceramics and numismatic evidence dated this construction (and its abandonment) to before the arrival of Islam. ${ }^{79}$ It seems likely given the available evidence that, notwithstanding the historical descriptions of the canal, the majority 
of the city water would have been provided using wells, and some open or covered reservoirs (hauz), whereas the canals would have flown through the suburban area, possibly through the outer walls, but not through the centre of the city.

As an additional observation, at Marv, two additional canals flank the city, which appear to have been used for specific purposes. The Hormuzfarra canal, for example, having watered the surburb outside the southwest quarter of the city, then passes through a vast potters quarter that then had seemingly sole use of this water source, before it passed beyond the city. ${ }^{80}$ A similar scenario is highly likely at Balkh, although industrial areas such as the ceramics workshops have not been located. Nevertheless, proxy evidence for production of this type, in the form of ceramic kiln furniture, can be seen on the surface outside the inner east wall of the city.

Plotting the named villages in geographical space (see above) reveals a sizeable 'shadow' of less-densely occupied land to the north of the city (Figure 3). Doubtless, the character of this area results in part from the water used by the city and its suburbs, but there is an additional topographic feature, which must be borne in mind. The area immediately north of the Balkh citadel, outside the walled city, is a zone of comparatively low ground, with very little modern occupation. On a Corona satellite image from the spring of 1970, during a period of exceptionally high water flow, this region is entirely flooded, clearly demonstrating that it is a natural basin gathering outlets from the nearby channels (Figure 7). ${ }^{81}$ On the ground, evidence of a patchwork of banks and ditches indicates that this seasonally inundated land may have been utilised as fertile ground. Meanwhile, a series of lone structures, located by Philippe Marquis ${ }^{82}$ and similar in appearance to the $k o ̈ s h k s$ of the Marv oasis, ${ }^{83}$ points to the existence of isolated suburban structures in the extra-mural area, as a part of the wider urban layout. The third canal at Marv, the Raziq Canal, seems to have been designated a similar purpose, once the earlier city of Gyaur Kala was no longer the primary locus of urban 
administration. Remains of large palatial structures are wedged awkwardly between the old and the new city (Sultan Kala), with nearby open field systems indicating that this canal was primarily watering these suburban areas after the tenth century, and possibly earlier.

\section{[insert Figure 7 here]}

Extensive gardens were clearly a feature of the urban topography at Balkh, although their typically ephemeral nature renders detailed archaeological reconstruction almost impossible. In the colourful accounts of the winter court of the Ghaznavids at Balkh, gardens play a fundamental role as the primary locus of political activity, the diwan most often being set up in the open air, rather than inside the palace. ${ }^{84}$ Glimpses of lavish events taking place within the royal garden portray luxurious planting and a plentiful water supply for which canal-fed irrigation would have been essential. ${ }^{85}$ A number of other gardens and hunting grounds are identified within the same accounts, but appear to be placed some way from the city. The persistence of the toponym chaharbagh ${ }^{86}$ at several locations across the wider oasis is perhaps suggestive of the enduring legacy of formalised open areas in the extra-mural area. References to the royal gardens, however, intimate that in the time of the Ghaznavids and later on these lush spaces were in fact located within the urban enceinte. One candidate for the location of such a space is a large square enclosure within the western walls (500m $\mathrm{x}$ 500m), with an unusual alignment, visible on Corona satellite imagery from 1970 (Figure 8). What can be seen in the photograph is a bounded open space respected by the alignment of adjacent cultivated plots, which have subsequently completely transformed the area. It is impossible to verify the age of such an enclosure based on remote imagery, but excavation of eroded fragments of mud-walls in this area, if they survive, might in future provide further clues as to the origins of this feature. Tantalisingly, however, this square feature is located in precisely the area suggested by McChesney as the location for the remains of a seventeenth century palace, or dawlatkhanah, within the walls of the city, which had its origins as a 
chaharbagh. ${ }^{87}$ A contemporary description of this complex is given by Mahmud b. Ali Wali, and permits a detailed reconstruction of its layout, an important part of which was devoted to lush gardens. Although McChesney cross-references these buildings to ruins photographed by Foucher in the early twentieth century, ${ }^{88}$ these structures are no longer extant, and it is not clear whether they too would have been originally located within this same square enclosure identified in the northwestern part of the walled city. Whether or not these gardens can be confirmed in this area, the seventeenth century narrative strongly suggest that canal water was in fact brought within the city walls to feed these gardens, at least within the lower walled area, and probably entered the western and eastern halves separately.

\section{[insert Figure 8 here]}

\section{Conclusions}

On the basis of the evidence presented here, the establishment, or at least reorganisation of the hierarchical hydrological network of Balkh took place after a dramatic shift in the watercourses to the eastern parts of the delta, in the first quarter of the ninth century. How much of the resulting system reused prior canals and dams requires further investigation of individual palaeochannels, and refined archaeological chronologies for individual sites, but the locale of Balkh itself clearly remained central throughout. The shift in the primary river course is supported by a number of archaeological sites in the extreme north of the Balkh section of the delta with no significant quantities of tenth-thirteenth century ceramics, suggesting that the zone of agriculture shrank at this point. Nevertheless, the idea that there was no sustainable settlement in the western Aqcha delta region prior to the earthquake is challenged by the existence of several sites with pre-Islamic material from this region.

Considering all the evidence together, it seems likely that events in the early ninth century led to new developments in the agricultural area in the Aqcha delta which developed the existing fringe settlements in the region and prompted the expansion of the central node at al-Sidra. 
The real changes in the hydrological system after this time can be seen as a complex mechanism of control. Dividing the water between eighteen or more branches required centralised administration, in order to apportion the required shares accordingly. The efficiency of water management is demonstrated most clearly by the maintenance of large agricultural settlements at the fringes of the delta, and the ends of the canals, where the separation between the arid steppe and the cultivated zone was vividly marked. Within the system, the city of Balkh is not outstanding in terms of its water supply, being fed just as other settlements, albeit probably by a number of small canals irrigating the western and eastern parts of the lower city. In this way, the provision of flowing water appears not to be as much of a structuring principle to the urban space as at many other comparable cities, such as Marv and Bukhara, perhaps owing to the fact that the fresh water table is high and easily accessible by wells.

While it is tempting to see the development of the hydrological network as simply hierarchical, the branches of canals indicate that the motivation behind its maintenance is to support the delta as a whole, rather than prioritise specific settlements or regions. A shift in focus can already be seen in the description of Mo'min, and progresses further by the time of the nineteenth century accounts. With the growth of Mazar-e Sharif on the uppermost eastern branch of the delta, increasing amounts of water were channelled eastwards towards the expanding complex. Individual settlements were abandoned throughout the delta, but the edges of the agricultural area see the clearest contraction, as large fringe settlements like Zadiyan and Siahgird become unsupportable. Although the city of Balkh was almost completely abandoned in the $19^{\text {th }}$ century, many of the canals remain, as evidence by the continued use of their names, and the surviving names of villages. The system then, and indeed now, exemplifies the Central Asian oasis city: whereby large fertile agricultural lands were sustained by the careful management of water distribution from a single source. Control 
of the water resources rested with the centralised administrative powers that oversaw its apportionment, but as a result of the need to maintain substantial productive rural land in a limited area, the pattern of occupation was a dispersed one. In this way, the numerous small cities, towns and villages were tightly bound, and carefully balanced, in an intricate hydrological network. 


\section{Figure Captions}

Figure 1: Map of the Balkh-ab delta indicating archaeological sites after Ball (1982) and locations mentioned in the text.

Figure 2: Map of the villages named by Mo'min and the comparison of these names that appear in the gazetteer of Adamec. Thiessen polygons have been drawn around each point to represent an arbitrary equally divided region, coloured according to the canal ascribed as watering the village. Villages are show as black circles; those with a cross through them are also mentioned by Adamec (below). Note that no villages were located for four of the canals enumerated by Mo'min and these could therefore not be reconstructed (Nahr-e Shahi, Juy-e Qizil Ribat, the Nahr-e Mushtaq, and Dastjird).

Figure 3: Map of the villages named by Adamec in comparison with those mentioned by Mo'min (shown with a cross through them). Canal zones generated as Figure 2. Villages are shown as black circles; those with a cross through them are also mentioned by Mo'min. Grey crosses mark the locations of villages mentioned by Mo'min that do not appear in the nineteenth century descriptions of the canals.

Figure 4: Dataset augmented from the Ball Gazetteer using USGS Orbview-3 imagery, giving an impression of the density archaeological settlements (largely tells) in the central area of Balkh-ab Delta, just to the north of the city of Balkh.

Figure 5: USGS Orbview-3 satellite image of the core area of the ruins of Siahgird and surrounding field systems.

Figure 6: USGS Orbview-3 satellite image of the ruins of the central walled square settlement at Zadiyan.

Figure 7: Corona satellite image from 1970 showing an extensive seasonally inundated area immediately north of the Balkh citadel (courtesy of USGS). 
Figure 8: Corona satellite image from 1970 of the western walled suburban area of Balkh, including the outline of a large square structure, which may be the historical outline of a garden or chaharbagh (courtesy of USGS). 


\section{Bibliography}

Adamec, L. W. 1979. Historical and Political Gazetteer of Afghanistan. Volume 4: Mazar-iSharif and North-Central-Afghanistan. Graz: Akad. Druck- und Verl.-Anst.

Akhmedov, B. A. 1982. Istoria Balkha (XVI-pervaia polvina XVIII v.). Tashkent: Izadatel'stvo 'FAN'.

Ambraseys, N. N. 1982. A History of Persian Earthquakes. Cambridge Earth Science Series. Cambridge; New York: Cambridge University Press.

Ball, W. 1982. Archaeological Gazetteer of Afghanistan (Catalogue Des Sites Archéologiques d’Afghanistan). 2 vols. Synthèse no 8. Paris: Editions Recherche sur les civilisations.

Barger, E., and P. Wright. 1941. Excavations in Swat and Explorations in the Oxus Territories of Afghanistan: A Detailed Report of the 1938 Expedition. Memoirs of the Archaeological Survey of India 64. Calcutta: Government of India Press.

Bartol'd, V. 1928. Turkestan Down to the Mongol Invasion. Translated by H. A. R Gibb. 2nd ed. London: Luzac and Co.

Bartol’d, V. 1965. 'K istoriia orosheniia Turkestana’. In O. G. Bol’shakov (ed.) V. V. Bartol'd Sochineniia vol. 3. Moscow: Izdatel’stvo Nauka. Pp. 97-236.

Bartol'd, V. 1971. 'Istoriko-geograficheskii obzor Irana'. In I.P. Petrushevskiǐ (ed.) V. V. Bartol'd Sochineniia vol. 7. Moscow: Izdatel’stvo Nauka. Pp. 31-228.

Bartol’d, V. 1973. ‘Otchet v komandirovke v Turkestane. Avgust-dekabr 1920 g.’. In A.S. Tveritinova (ed.) V. V. Bartol’d Sochineniia vol. 8. Moscow: Izdatel’stvo Nauka. Pp. 366-396.

Bartol'd, V. 1984. An Historical Geography of Iran. Edited by C.E. Bosworth, translated by S. Soucek. Princeton, N.J: Princeton University Press. 
Beyhaqi, Abu’l-Fazl Muhammad b. Husayn. 2011. The History of Beyhaqī: The History of Sultan Mas 'ud of Ghazna, 1030-1041. Translated by C.E. Bosworth (3 vols). Ilex Foundation Series 6. Boston, MA: Harvard University Press.

Bosworth, C. E. 1969. 'Abū 'Abdallah al-Khwārazmī on the Technical Terms of the Secretary’s Art: A Contribution to the Administrative History of Mediaeval Islam'. Journal of the Economic and Social History of the Orient 12 (2): 113-64

Esper, J., F.H. Schweingruber, and M. Winiger. 2002. ‘1300 Years of Climatic History for Western Central Asia Inferred from Tree-Rings’. The Holocene 12 (3): 267-77.

Fouache, E., R. Besenval, C. Cosandey, C. Coussot, M. Ghilardi, S. Huot, and M. Lamothe. 2012. 'Palaeochannels of the Balkh River (northern Afghanistan) and Human Occupation since the Bronze Age Period'. Journal of Archaeological Science 39 (11): $3415-27$.

Foucher, A. 1942. La vieille route de l'Inde de Bactres à Taxila. Vol. 1. 2 vols. Paris: Les Éditions d'art et d'histoire.

Gardin, J.-C. 1957. Céramiques de Bactres. Mémoirs de La Délégation Archéologique Française En Afghanistan 15. Paris: Librairie C. Klincksieck.

Gibb, H. A. R. 1923. The Arab Conquests in Central Asia. London: The Royal Asiatic Society.

Hafez-e Abru. 1982. Horāsān zur Timuridenzeit nach dem Tārīh-e Hafez-e Abrū. Edited and translated by D. Krawulsky. Wiesbaden: Dr. Ludwig Reichert Verlag Hamdallah Mostawfi al-Qazvini. 1919. The Geographical Part of the Nuzhat al-Qulūb. Translated by G. Le Strange. Leiden; London: Brill.

Herrmann, G. 1999. Monuments of Merv: Traditional Buildings of the Karakum. London: Society of Antiquaries of London. 
Ibn Hawqal, Abu'l-Qasim b. 'Ali al-Nasibi. 1964. Configuration de la Terre (Kitab Surat alArd). Translated by J. H. Kramers and G. Wiet. Vol. 2. 2 vols. Paris: Éditions G.-P. Maisonneuve \& Larose.

Ibn Khordādhbeh, Abu’l-Qasim 'Ubayd Allah b. 'Abd Allah. 1889. 'Kitāb Al-Masālik Wa'lMamālik'. In M. J. de Goeje (ed.) Bibliotheca Geographorum Arabicorum - Pars Sexta. Leiden: Brill. Pp. ' - \^r.

Kennedy, H. 1999. 'Some Ancient and Medieval Texts about Merv’. In G. Herrmann Monuments of Merv: Traditional Buildings of the Karakum. London: Society of Antiquaries of London. Pp. 121-6.

Khazeni, A. 2010. 'The City of Balkh and the Central Eurasian Caravan Trade in the Early Nineteenth Century'. Comparative Studies of South Asia, Africa and the Middle East 30 (3): 463-72.

Qodama b. Ja far al-Katib al-Baghdadi, Abu’l-Faraj. 1889. ‘Kitāb Al-Kharadj’. In M. J. de Goeje (ed.) Bibliotheca Geographorum Arabicorum - Pars Sexta. Leiden: Brill. Pp. $11 \leq-Y T 4$.

Lunina, S. B. 1962. ‘Goncharnoe proizvodstvo v Merve X nachale-XII vv.’. In M. E. Masson (ed.) Keramika antichnogo i sredenvekovogo Merva. Trudy IuTAKE 11. Ashgabat: Izdatel’stvo Turkmenskogo Filiala Akdemii Nauk SSR. Pp. 217-418.

Masson, M. E. (ed.) 1978. Materialy po arkheologǐ̌ Merva. Trudy IuTAKE 16. Ashgabat: Izdatel'stvo Ylym.

McChesney, R. D. 1991. Waqf in Central Asia: Four Hundred Years in the History of a Muslim Shrine, 1480-1889. Princeton, NJ: Princeton University Press.

McChesney, R. D. 2009. ‘An Early Seventeenth-Century Palace Complex (Dawlatkhāna) in Balkh’. Muqarnas 26: 95-118. 
Miller, K. 1929. Mappae Arabicae: Arabische Welt -Und Landerkarten. Asia II: Nord- Und Ostasien. Stuttgart, Germany: Selbstverlag des Herausgebers.

Minorsky, V. (trans.) 1937. Hudūd Al- 'Ālam. 'The Regions of the World', a Persian Geography 372 A.H.-982 A.D. Oxford: Oxford University Press.

al-Moqaddasi. 2001. The Best Divisions for Knowledge of the Regions: Aḥsan Al-Taqāsìm Fī Ma 'rifat Al-Aqālìm. Translated by B. Collins. Reading: Garnet.

Mukhtarov, A. 1993. Balkh in the Late Middle Ages. Translated by R. McChesney. Bloomington, Ind.: Indiana University, Research Institute for Inner Asian Studies. Nasir Khusraw. 1881. Sefer Nameh: Relation du voyage de Nassiri Khosrau. Translated by C. Schefer. Paris: Librarie de la Société Asiatique de l’École des Langues Orientales Vivantes.

Oberhänsli, H., N. Boroffka, P. Sorrel, and S. Krivonogov. 2007. 'Climate Variability during the Past 2,000 Years and Past Economic and Irrigation Activities in the Aral Sea Basin’. Irrigation and Drainage Systems 21 (3-4): 167-83.

Rante, R., A. Raimkulov, and S. Adilov. 2013. Mission Archéologique Dans l'Oasis de Boukhara: Rapport Préliminaire, Campagne 2012. Paris: Musée du Louvre-LA3M (UMR7298).

Rout, B. 2008. How the Water Flows: A Typology of Irrigation Systems in Afghanistan. Issue Paper Series: Water Management, Livestock and the Opium Economy. Kabul: Afghanistan Research and Evaluation Unit. Retrieved online 6 ${ }^{\text {th }}$ June 2014 at: http://www.areu.org.af/Uploads/EditionPdfs/811ETypology\%20of\%20Irrigation\%20Systems.pdf.

Salakhetdinova, M.A. 1970. 'K istoricheskoǐ toponimike Balkhskoǐ Oblasti'. Palestinskiǐ Sbornik 21: 222-8. 
Salvatori, S., and M. Tosi. 2008. The Archaeological Map of the Murghab Delta. Volume III. The Bronze Age and Early Iron Age in the Margiana Lowlands: Facts and Methodological Proposals for a Redefinition of the Research Strategies. Oxford: Archaeopress.

Shakur, M. A. 1947. A Dash through the Heart of Afghanistan: Being a Personal Narrative of an Archaeological Tour with the Indian Cultural Mission. Peshawar: Shakur.

Sourdel-Thomine, J. 1953. ‘Deux Minarets D’époque Seljoukide En Afghanistan’. Syria 30 (1/2): 108-36.

Subtelny, M. 2007. Timurids in Transition: Turko-Persian Politics and Acculturation in Medieval Iran. Leiden: Brill.

Le Strange, G. 1905. The Lands of the Eastern Caliphate: Mesopotamia, Persia, and Central Asia from the Moslem Coquest to the Time of Timur. Third Edition. London: Frank Cass \& Co.

al-Tabari, al-Qadi al-Imam Abu'l-Tayyib Tahir b. 'Abd Allah. 1987. The History of alTabarī (Tarīkh al-rusul wa'l-mulūk). Volume 32: The Reunification of the 'Abbāsid Caliphate. Translated by C.E. Bosworth. Albany, NY: State University of New York Press.

Thomas, D. C., F. J. Kidd, S. Nikolovski, and C. Zipfel. 2008. 'The Archaeological Sites of Afghanistan from Google Earth’. Aerial Archaeology Research Group News 37: 2230.

Togan, Z. V. 1970. 'The Topography of Balkh down to the Middle of the Seventeenth Century’. Central Asiatic Journal 14: 277-88.

Tolstov, S. P. 1960. Nizov'ia Amudar'i Sarykamysh, Uzbǒ̀, istoriia formirovaniia i zaseleniia. Materialy Khorezmskoř Ekspeditsiř 3. Moscow: Izdatel’stvo Akademii Nauk SSSR. 
Torell, G. L., and F. A. Ward. 2010. 'Improved Water Institutions for Food Security and Rural Livelihoods in Afghanistan’s Balkh River Basin’. Water Resources Development 26 (4): 613-37.

Volin, S. L., A. A. Romaskevich, and A. Yu. Yakubovskii, ed. 1939. Materialy po istorii Turkmen i Turkmenii. Vol. 1. Moscow; Leningrad: Izdatel'stvo Akademii Nauk SSSR.

Voenno-topograficheskoe upravlenie General’nogo shtaba 1983-1985. Afganistan (1:50,000): J42 97-99 (A-Г); J42 109-111(A-Г).

Williams, T. 2007. 'The City of Sultan Kala, Merv, Turkmenistan: Communities, Neighbourhoods and Urban Planning from the Eighth to the Thirteenth Century'. In Cities in the Pre-Modern Islamic World: The Urban Impact of Religion, State and Society, edited by A. K. Bennison and A. L. Gascoigne. 1st ed. Oxford: Routledge. Pp. 42-62.

Wordsworth, P. (forthcoming). 'Connecting the early Islamic City: Balkh in geographical networks’. In A. Azad, E. Herzig, P. Marquis and P. Wordsworth (eds) Early Islamic Balkh: History, Landscape and Material Culture. I. B. Tauris.

Young, R. S. 'The South Wall of Balkh-Bactra'. American Journal of Archaeology 59 (4): 267-276. 
${ }^{1}$ This article was researched as part of the Balkh Art and Cultural Heritage (BACH) Project at the University of Oxford. This three-year (2011-2014) initiative was funded by a Leverhulme Trust Research Grant (RPG-172), with the aim to explore the early Islamic city of Balkh and its environs. The Principal investigator for the project was Professor Edmund Herzig. I would to express my sincere thanks to Edmund Herzig and Arezou Azad for their encouragement as my colleagues in this project. I would also like to thank in particular the Délégation Archéologique Française en Afghanistan (DAFA) for supporting this work, both academically and logistically in the field, and I owe a huge amount to the knowledge of Phillipe Marquis and Julio Bendezu-Sarmiento without whom this work would not have been possible. It is my great regret that the two scholars who laid the foundations for all future work on the archaeology of the Balkh region, Roland Besenval and Chahriyar Adle, are no longer with us, and I am extremely grateful for their input in the early stages of my research. My thanks should also be extended to the two anonymous reviewers of this article, whose comments were extremely valuable. Finally, I should like to thank Warwick Ball, as the first to pioneer comprehensive mapping of sites in Afghanistan, and whose monumental Gazetteer has remained the cornerstone of archaeology in Afghanistan since it was published; it contributes in no small part to the article presented here.

${ }^{2}$ River deltas or basins where the water does not flow into a larger body, i.e. sea or lake, but drains completely into the soil. In the Central Asian cases, this is often through a dendritic delta system that is completely or partially canalized for irrigation.

${ }^{3}$ Tolstov 1960; Masson 1978.

${ }^{4}$ Salvatori and Tosi 2008; Rante et al. 2013

${ }^{5}$ Which began with the monumental work of Foucher, La vieille route de l'Inde de Bactres à Taxila (1942).

${ }^{6}$ Togan 1970; Mukhtarov 1993.

${ }^{7}$ McChesney 1991. This work was added to and expanded by Subtelny (2007) who delved further into the endowments surrounding the shrine of 'Ali in Mazar-e Sharif.

${ }^{8}$ Fouache et al. 2012.

${ }^{9}$ Rout 2008: 3-4.

${ }^{10}$ Oberhänsli et al. 2007: 171. Long term trends from tree-ring data in the mountainous zones somewhat contradict the Aral cores, but suggests that the greatest change in climate occurred between 1300-1800 CE, when the region was considerably colder on average than at present (Esper, Schweingruber, and Winiger 2002).

${ }^{11}$ Gibb 1923: 15-6, 31.

12 Torell and Ward 2010: 616.

${ }^{13}$ Fouache et al. 2012: 3426.

${ }^{14}$ Ambraseys 1982: 37, note 11.

${ }^{15}$ Fouache et al. 2012: 3417. Note that Ambraseys believes the inundation of al-Sidra to be an event of liquifaction and a general rise in the water table, rather than a specific redirection of the river (Ambraseys 1982: 37, note 12).

${ }^{16}$ Qodama b. Ja' far 1889: 161-2; Y II- Y).

${ }^{17}$ Fouache et al. 2012: 3420. OSL (Optically Stimulated Luminesce dating) is a method for dating buried deposits based on the absorption of energy from background radiation released in sediment. Essentially, the dating clock is reset by exposure to light, so this techinque pinpoints the last time these deposits were exposed.

${ }^{18}$ Bartol'd 1971: 57 (English trans., Bartol'd 1984: 31)

${ }^{19}$ Ball 1982 (vol. 1):152; 199; 274. 
${ }^{20}$ Barger and Wright 1941: 54.

${ }^{21}$ Shakur 1947: 71.

${ }^{22}$ This material is now held in the collections of the Victoria and Albert Museum, London. I would like to express my sincere thanks to the V\&A for granting access to examine these hitherto unpublished sherds.

${ }^{23}$ Gardin 1957: 112.

24 Akhmedov 1982: 32.

25 The latest apparent reference to al-Sidra is in a very different Persianised form, 'Se Darre' (three valleys), in the eleventh century Safarname of Nasir Khusraw (1881: 263). From the geographical context of the narrative, this appears to correspond to the correct approximate location of al-Sidra/Aqcha, although the name does not appear in this form in any other source. There is a reference to al-Sidra in Hamdallah Mostawfi al-Qazvini's Nozhat al-Qolub (1919: 172) from the mid-fourteenth century, but this is very likely copied from an earlier medieval geographical work.

${ }^{26}$ Note that Fouache and colleagues divide the palaeochannels into four core systems (2012: 3246), but they are cumulatively adapted into new systems, rather than sequentially abandoned. The 'core' I refer to here is the primary zone of occupation around Balkh prior to the flourishing of the wider Aqcha area after the $9^{\text {th }}$ century.

27 al-Tabari 1987: 65.

28 al-Moqaddasi 2001: 245.

${ }^{29}$ See Miller (1929: Tafeln 54-6) for an overview of the cartographic material.

${ }^{30}$ Ibn Hauqal 1964 (vol. 2): Carte 21.

${ }^{31}$ Minorsky 1937: 108.

${ }^{32}$ Hafez-e Abru 1982.

${ }^{33}$ Mukhtarov 1993: 72-5.

${ }^{34}$ Salakhetdinova 1970.

${ }^{35}$ Mukhtarov 1993: 72.

${ }^{36}$ Subtelny 2007: 216.

${ }^{37}$ See Subtelny (2007) for an extensive discussion of waqf documents in Central Asia in the Timurid period and their relevance for the structuring of hydrological systems.

${ }^{38}$ Mukhtarov 1993: 72.

${ }^{39}$ Note that in Hafez-e Abru's account there is the additional Band-e Hendovan (1982 [vol. 1]: 71), which, although it is the name of one of the canals, likely refers to either the same or an additional dam on the river.

${ }^{40}$ Fouache et al. 2012: 3417.

${ }^{41}$ Details of the USAID MISTI database can be found online at: https://www.usaid.gov/data/dataset/2cafcb62-00da-4f83-ac7b-471bccf8528f

${ }^{42}$ Voenno-topograficheskoe upravlenie general'nogo shtaba 1983-1985

${ }^{43}$ Adamec 1979

${ }^{44}$ The areas around each village were calculated using a method known as Thiessen Polygons, whereby for any given node (in this case the villages) a line of equal distance is drawn between it and the nearest other nodes, forming for each a polygon which represents the area for which this would be the nearest village. Note that these regions are arbitrary constructions used in this instance purely for diagrammatical purposes.

45 McChesney 1990: 40-41; Subtelny 2007: 214.

${ }^{46}$ Hafez-e Abru 1982 (vol. 1): 70-71.

${ }^{47}$ al-Moqaddasi 2001: 281.

${ }^{48}$ Adamec 1979

49 Ibid.: 250. 
${ }^{50}$ Ibid.: 254.

${ }^{51}$ Fouache et al. 2012: 3426 Fig. 9.

${ }^{52}$ See Thomas et al. (2008) for an exhaustive evaluation of this technique as used more widely in Afghanistan. It should be noted that a few of these sites are marked on the maps accompanying Ball's Gazetteer (1982: map 81), having been transcribed from Soviet cartographic sources, but as with those detected remotely here, no names or further details are available for these sites.

${ }^{53}$ Roland Besenval, pers. comm.

${ }^{54}$ Pugachenkova 1976: 149-151. It should be noted that this dating relies heavily on the inference from the size of the unfired mudbricks used in the building's construction and should therefore be treated cautiously.

${ }^{55}$ Moqaddasī 2001: 281; Ibn Khordādhbeh 1889: 23.

${ }^{56}$ Volin, Romaskevich, and Yakubovskii 1939 (vol. 1): 176.

${ }^{57}$ Beyhaqi 2011 (vol. 1): 335; 345.

58 Adamec 1979: 546.

${ }^{59}$ Also known as Abu Hurayra (Ball 1982 (vol. 1): 28).

${ }^{60}$ Sourdel-Thomine 1953: 124.

${ }^{61}$ Although the minaret has received considerable attention in comparison to other remains in the Balkh data, there is frustratingly little mention of the wider site at Zadiyan/Daulatabad, and no substantial investigation has been made of the settlement.

${ }^{62}$ Ball 1982 (vol. 1): 287.

${ }^{63}$ Ibid.: 152. While there is a reference to Shaykh Shurakh-e Khanabad on the canal list of Mo'min, its placement at the beginning of the sequential list of settlements means that its identification as the archaeological site of Khanabad is ambiguous. The presence of a large settlement at the northmost reaches of this canal, however, is clear from the extent of the ruins in this region.

${ }^{64}$ See Wordsworth (forthcoming) for an exploration of the settlements of the Balkh oasis with respect to the routes connecting Balkh and its broader hinterland.

${ }^{65}$ Bartol'd 1965: 141. We find from al-Khawarizmi's description of the system that these outlet holes, or rather the measurement that relates to them is referred to as a bast (Bosworth 1969: 152).

${ }^{66}$ Bosworth 1969: 152.

67 al-Moqaddasi 2001: 269.

${ }^{68}$ Bartol'd 1926: 413.

${ }^{69}$ Three such attacks on the irrigation system are quoted by Mukhtarov 1993: 71

${ }^{70}$ Khazeni 2010: 463.

${ }^{71}$ McChesney 1991: 40-1.

72 Subtelny 2007: 224-225.

73 Adamec 1979: 78.

74 See Gardin (1957: 105-7) for coarse evidence of occupation chronology of the citadel.

75 Minorsky 1937: 108; Hafez-e Abru 1982 (vol. 1): 65-66.

${ }^{76}$ Williams 2007: 55.

77 Ibn Hawqal 1964 (vol. 2): 433.

${ }^{78}$ Foucher 1942 (vol. 1): Plate VI (b).

${ }^{79}$ Young 1955: 273.

${ }^{80}$ Lunina 1962: 217-219.

${ }^{81}$ Declassified Corona high-resolution stereo panchromatic satellite imagery, courtesy of USGS. Captured $29^{\text {th }}$ May 1970.

${ }^{82}$ Philippe Marquis, pers. comm. 
${ }^{83}$ Herrmann 1999.

${ }^{84}$ Beyhaqi 2011 (vol. 1): 230.

85 Ibid.: 398.

${ }^{86}$ Literally "four gardens", but a name given to formal garden enclosures more broadly in the Persianate world.

${ }^{87}$ McChesney 2009

${ }^{88}$ Ibid.: 111. 